\title{
Where Did All the Aid Go? \\ An Empirical Analysis of Absorption and Spending
}

Shekhar Aiyar and Ummul Ruthbah 



\title{
IMF Working Paper
}

\author{
African Department
}

\begin{abstract}
Where Did All the Aid Go? An Empirical Analysis of Absorption and Spending ${ }^{1}$
\end{abstract}

\section{Prepared by Shekhar Aiyar ${ }^{2}$ and Ummul Ruthbah ${ }^{3}$}

Authorized for distribution by Andrew Berg

February 2008

\begin{abstract}
This Working Paper should not be reported as representing the views of the IMF. The views expressed in this Working Paper are those of the author(s) and do not necessarily represent those of the IMF or IMF policy. Working Papers describe research in progress by the author(s) and are published to elicit comments and to further debate.

This paper examines the macroeconomic usage of aid using panel data for a broad sample of aidrecipients. By definition an increase in aid must go toward a reduction in the current account balance (absorbed aid), an increase in capital outflows, or reserve accumulation. It is found that short-run absorption is typically very low, with much aid exiting through the capital account. Moreover, aid spending, defined in terms of the increase in government fiscal expenditures as a result of aid, is significantly greater than aid absorption, implying that aid systematically leads to an injection of domestic liquidity in recipient economies. The evidence here may help illuminate the rather weak link between aid and growth found in the literature. It reinforces the case for greater coordination between fiscal and monetary authorities in response to aid inflows.
\end{abstract}

JEL Classification Numbers:E01, E29, E60, F41, O11, O40.

Keywords: Aid, Spending, Absorption, Growth.

Author's E-Mail Address:mailto:SAiyar@imf.org

\footnotetext{
${ }^{1}$ We would like to thank Andrew Berg for initiating and inspiring this line of research, and Abhijit Banerjee, Oya Celasun, Esther Dufflo and Thierry Tressel for providing several useful suggestions on an earlier draft of this paper. All mistakes remain our own.

${ }^{2}$ International Monetary Fund

${ }^{3}$ Massachusetts Institute of Technology
} 


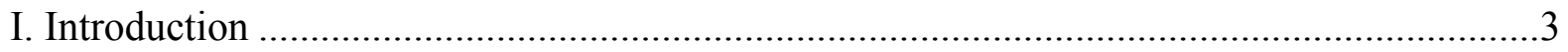

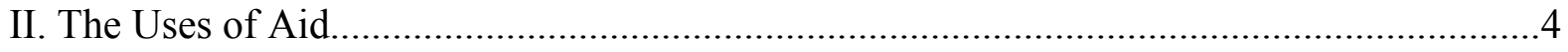

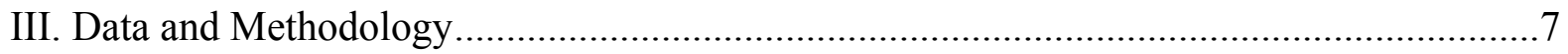

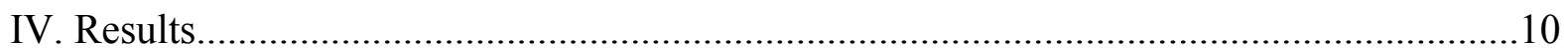

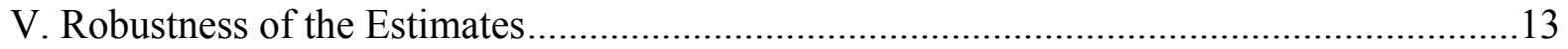

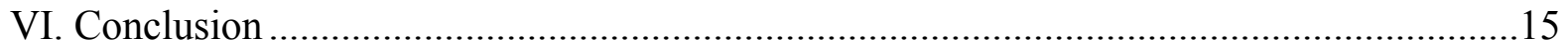

\section{Tables}

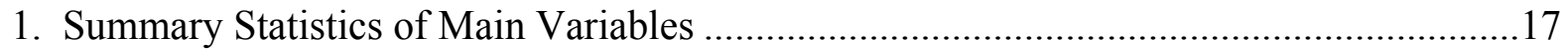

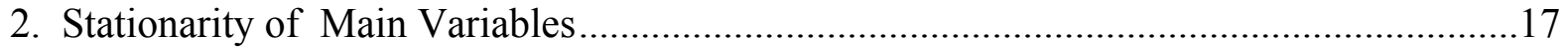

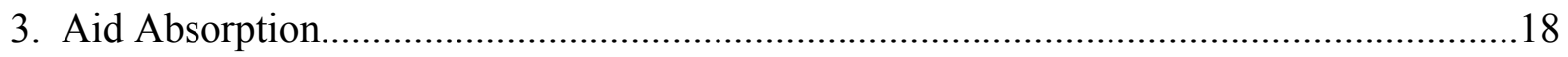

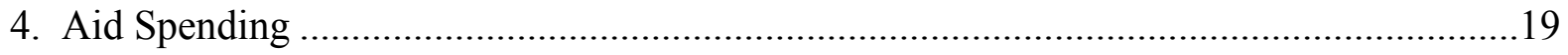

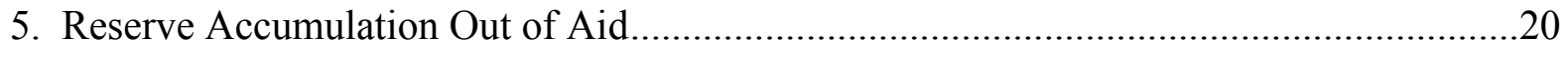

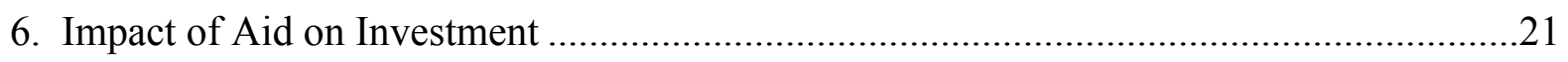

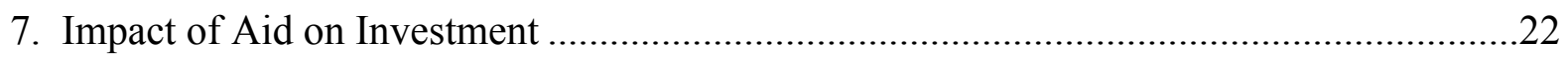

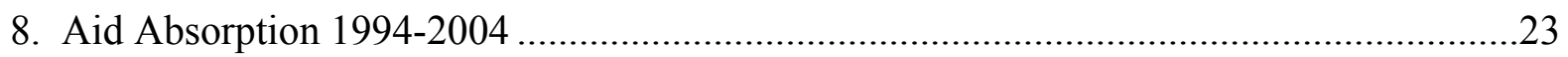

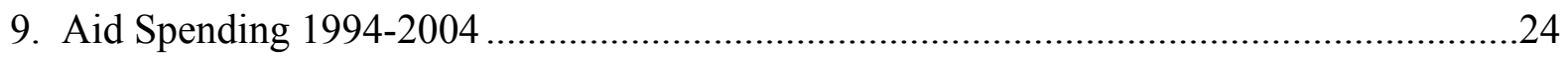

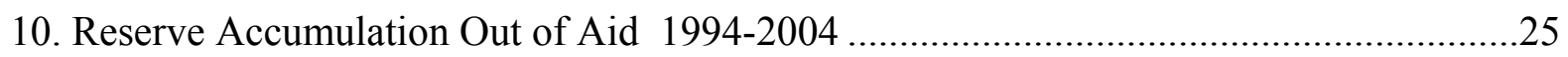

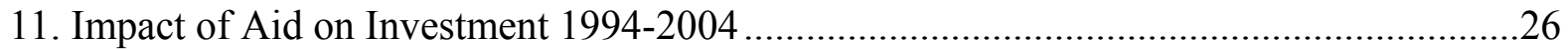

12. Aid Absorption in Major Aid Receiving Countries .....................................................27

13. Aid Spending in Major Aid Receiving Countries.....................................................28

14. Reserve Accumulation Out of Aid - Major Aid Receiving Countries ...........................29

15. Impact of Aid on Investment - Major Aid Receiving Countries ...................................30

\section{Figures}

1. Time Paths of Absorption and Spending .................................................................11

\section{Appendixes}

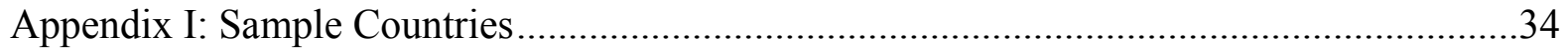

\section{References}

References. 


\section{INTRODUCTION}

Unlike international flows of capital, aid usually accrues to governments, not private agents, and the aid dollars are held in the first instance by the Central Bank. Governments can use the aid to increase spending, typically by increasing domestic expenditure and running larger budget deficits. Meanwhile the Central Bank, by selling aid dollars, can enable the absorption of aid through a widening current account deficit. Aid must be absorbed for there to be a transfer of resources from donor to recipient country. Most of the aid literature tacitly assumes that absorption and spending are both complete and equivalent, i.e. that every aid dollar leads to a corresponding transfer of resources, which the government uses to boost consumption or investment.

This paper subjects the macroeconomic usage of aid to more critical scrutiny. If absorption is incomplete, so is the transfer of resources. Moreover, an imbalance between absorption and spending has various macroeconomic consequences, some of them potentially adverse. In particular, a small number of detailed case studies (Berg et al (2007)) of countries that have recently seen large jumps in aid find that, typically, spending exceeds absorption, resulting in an injection of liquidity into the economy. This raises several questions of macroeconomic management, such as the choice of whether to countenance possibly higher inflation or to risk crowding-out the private sector through domestic sterilization.

We attempt to systematize the evidence on aid absorption and spending, by looking at a broad sample of aid recipients over a thirty year period. Using a dynamic panel framework, we are able to obtain estimates for both short-run and long-run absorption and spending, while controlling for variables that may be independently responsible for movements in the current account balance and the fiscal balance. The closest parallel to our exercise here is Bosworth and Collins (1999), who examine the absorption of private capital flows for a sample of developing countries, and find that it is only about two-thirds of the flow on average. However, to the best of our knowledge, this is the first systematic attempt to analyze the absorption of aid inflows, to track the dynamics of aid usage, and to combine the analysis with a consideration of capital outflows and fiscal policy.

To preview our main results, we find that absorption is very low in the short-run, but increases substantially over time. The remainder of the aid is likely to exit the country through an initial increase in capital account outflows, which is reversed as aid is absorbed with long lags. Spending considerably exceeds absorption, in both the short- and long-run. Finally, of the aid that is absorbed, less than half goes toward increased investment. Moreover, the increase in public investment that does occur appears to some extent to crowdout private investment. Taken together these results-long lags in absorption, macroeconomic problems arising from the excess of spending over absorption, and the crowding-out of private investment - may help illuminate the weak relationship between aid and growth found in the literature. The results highlight the danger of unplanned increases in liquidity arising from the macroeconomic response to aid inflows, which may, in turn, require sterilization through higher interest rates and thus crowd-out private investment. Thus the case for more careful coordination between fiscal and monetary authorities in managing aid is strengthened. 
The paper is structured as follows. The next section develops the terminology and accounting framework we use, and briefly expounds the macroeconomic consequences of various policy responses to aid. Section III describes our data and empirical methodology. Section IV contains our main results, while Section V details various robustness tests and sub-sample results. The subsequent section concludes.

\section{THE USES OF AID}

From a balance of payments perspective, an increment in aid has three possible uses: it can finance a fall in net exports, it can be used to augment international reserves, or it can exit the country through capital outflows. Formally we can decompose the uses of aid using the simple balance of payments identity:

$C A B+K A B=\triangle R$

where $\mathrm{CAB}$ is the current account balance, $\mathrm{KAB}$ is the capital account balance, and $\mathrm{R}$ is international reserves. Net flows of aid have both current and capital account components; while grants and interest payments appear in the current account, loans and amortization appear in the capital account. Separating these components of aid from CAB and KAB, rearranging and taking differences yields:

$\triangle A=-\triangle N A C A B-\triangle N A K A B+\triangle \Delta R$

where $\mathrm{A}$ is net aid, NACAB is the non-aid current account balance and NAKAB is the nonaid capital account balance. ${ }^{4}$

There is a real transfer of resources from donor to recipient only if the aid is used to finance a widening of the current account deficit. If aid dollars are used to augment international reserves or to finance capital outflows, they have no real counterpart in increased consumption or investment. Thus we define absorption as the fall in the non-aid current account balance that is attributable to aid.

On the fiscal side we start with the identity:

$G O B=D R-D E+A$

where GOB refers to the government or fiscal balance, DR to domestic revenue, DE to domestic expenditure, and A to net aid. ${ }^{5}$ Rearranging and differencing yields:

\footnotetext{
${ }^{4}$ Formally: $A=$ Grants + Loans - Amortization - Interest ; $N A C A B=C A B-$ Grants + Interest $;$ and $N A K A B=K A B-$ Loans + Amortization .

${ }^{5}$ The terms government balance and fiscal balance are used interchangeably in this paper.
} 
where NAGOB refers to the non-aid fiscal balance. ${ }^{6}$ Because of fungibility between aidrelated spending and other spending, the non-aid fiscal balance is a better measure of government expenditure out of aid than a simple aggregate of aid-financed projects. We define spending as the fall in the non-aid fiscal balance that is attributable to aid.

It should be obvious that absorption and spending are not necessarily equivalent to each other. In some cases - aid in kind and aid-financed government imports being obvious examples - absorption and spending must indeed be equal. But in general, spending depends on the fiscal authority, while absorption is primarily controlled by the central bank's willingness to sell the aid dollars. Hence, absent perfect agreement and coordination between the fiscal authorities and the central bank, spending will differ from absorption. IMF (2005a) first examined the macroeconomic consequences of policy choices involving different mixes of absorption and spending. ${ }^{7}$ In the remainder of this section we provide a brief summary of what is entailed by different combinations of absorption and spending.

Full absorption and spending is the textbook response to aid, and is usually a tacit assumption in the aid literature. Absorption ensures that there is a real transfer of resources to the recipient country, while government spending reallocates resources from the traded goods sector to the sector receiving government investment. Some real exchange rate appreciation may be necessary to affect this reallocation of resources. ${ }^{8}$ This is because some combination of exchange rate appreciation and (if there is excess capacity) increased aggregate demand is necessary to generate the increased net imports that aid allows.

Neither absorbing nor spending the aid is equivalent to not receiving any aid in terms of macroeconomic impact. ${ }^{9}$ In principle aid recipients may choose this strategy to build-up international reserves from a perceived low level or to smooth volatile aid flows. In the longrun, however, this response is equivalent to forgoing aid.

Absorbing but not spending substitutes aid for domestic financing of the government deficit. The money supply shrinks as the central bank draws liquidity out of the domestic economy through foreign exchange sales. Where the initial level of domestically financed deficit

\footnotetext{
${ }^{6}$ There is a small accounting subtlety regarding equations 2.3 and 2.4. External loans are often shown "below the line" in countries' fiscal accounts, thus rendering equation 2.3 inaccurate. However, equation 2.4, in which all flows of aid are netted out of the left hand side, remains valid, and this is what we use in the paper.

${ }^{7}$ The framework and case studies developed there were further expounded and extended by Berg et al (2007), Aiyar, Berg and Hussain (2005), Bevan (2005), Foster and Killick (2006), IEO (2007), Isaard et al (2006), Gupta, Powell and Yang (2006) and Peiris and Saxegaard (2007).

${ }^{8}$ If traded goods production entails dynamic externalities absent elsewhere in the economy, this can lead to Dutch disease; a topic with a rich and extensive literature.

${ }^{9}$ Apart from any second-order effects on confidence as a result of higher international reserves.
} 
spending is too high, this can help stabilize the economy. Alternatively, this approach to aid may be used to reduce the level of public debt outstanding, crowding-in the private sector. The mechanism is that the central bank uses the proceeds from its sales of foreign exchange to buy back government debt.

Finally, spending and not absorbing the aid is similar to a fiscal stimulus in the absence of aid. IMF (2005) found that in a sample of five countries receiving large recent increments of aid, this was the modal response. The aid dollars stay in reserves, so the increase in government spending must be financed by government borrowing from the domestic private sector or by printing money. This response comes in two variants: unsterilized and sterilized. The unsterilized variant leads to an increase in the money supply and hence risks inflation. The sterilized variant employs treasury bills sales to avoid an expansion of the money supply, thereby raising interest rates. It combines a lack of transferred resources with a reallocation of existing resources from the private to the public sector.

\begin{tabular}{|c|c|c|}
\hline & Absorbed & Not Absorbed \\
\hline Spent & $\begin{array}{l}\text { - Textbook case where central bank } \\
\text { sells aid dollars and fiscal deficit rises } \\
\text { as aid is spent. } \\
\text { - Aid is used for public investment and } \\
\text { consumption. } \\
\text { - No change in money supply. Risks } \\
\text { Dutch disease. }\end{array}$ & $\begin{array}{l}\text { - Central bank accumulates foreign } \\
\text { exchange as reserves; fiscal deficit } \\
\text { rises as aid is spent. } \\
\text { - No real resource transfer. } \\
\text { - Unsterilized: Money supply rises. } \\
\text { Risks inflation. } \\
\text { - Sterilized: Crowding out of private } \\
\text { sector. Domestic debt accumulates. }\end{array}$ \\
\hline Not Spent & $\begin{array}{l}\text { - Central bank sells foreign exchange } \\
\text { but fiscal deficit remains unchanged. } \\
\text { - Helps achieve stabilization, provides } \\
\text { resources for private investment. }\end{array}$ & $\begin{array}{l}\text { - Central bank accumulates foreign } \\
\text { exchange as reserves; fiscal deficit } \\
\text { net of aid unchanged. } \\
\text { - No real resource transfer. } \\
\text { - No Dutch disease. } \\
\text { - Equivalent to saving aid, or to } \\
\text { rejecting aid (in long run). }\end{array}$ \\
\hline
\end{tabular}

One further issue of interest, especially with regard to the mixed empirical evidence on the impact of aid on growth ${ }^{10}$, is the question of how exactly absorbed aid is used. In particular,

\footnotetext{
${ }^{10}$ See Clemens, Radelet and Bhavani (2004) for a summary of the voluminous literature on aid and growth. Notable contributions to this literature are Rajan and Subramaniam (2005), Alesina and Weder (2000), Bauer
} 
absorbed aid may be expected to boost growth to the extent that it is used for public investment. However Boone (1994, 1995, 1996) found that aid flows were significantly correlated with government consumption, but not with government investment. These results are supported using new data by Eble (2006). In this paper we address the issue by attempting to ascertain aid's impact on investment. This allows us to examine how much absorbed aid actually finds its way into increased investment. Moreover, we examine whether the public investment engendered by aid has any crowding-out effect on private investment.

\section{Data AND Methodology}

The data used in this study are collected from the World Development Indicators (WDI), Global Development Finance (GDF) and the IMF's World Economic Outlook (WEO). Our sample uses annual data for the period 1970-2004. Coverage includes all low-income countries and all countries that received substantial aid (except those classified as uppermiddle income countries, which received aid mainly for political reasons) for which data on all the variables of interest were available. ${ }^{11}$

The sample consists of 95 countries (Appendix I); of these, 45 are from Sub-Saharan Africa and 19 from Latin America and the Caribbean. Table 1 shows summary statistics for several variables of interest. The mean aid-to-GDP ratio for the sample is 6.8 percent. Sub-Saharan Africa received the highest amount of aid, with a mean aid-to-GDP ratio of 9.7 percent. On average countries ran high current and fiscal deficits (net of aid), with Sub-Saharan Africa running the highest deficits.

There are no summary statistics for absorption and spending as we have defined the terms, because a country's current account and fiscal balance can and do change for several reasons other than aid. So, for example, the average NACAB / AID ratio for all countries in our sample is about -1.5 , which tells us nothing about absorption, but simply that on average countries' current account deficits are larger than their aid receipts. To obtain estimates for absorption and spending we need to examine the response of NACAB and NAGOB to changes in aid, while controlling for factors that may move the current account balance and the fiscal balance independent of aid.

(1971), Burnside and Dollar (2000), Collier and Dollar (2002), Dalgaard, Hansen and Tarp (2004), Hansen and Tarp (2000), Roodman (2004), Svensson (2003), and Adam and Bevan (2003).

${ }^{11}$ Countries that came into existence in the 1990s are excluded due to lack of a sufficiently long time-series. 
Accordingly, we specify the following regressions:

$$
\begin{aligned}
& N A C A B_{i t}=\alpha_{1 i}+\rho_{1} N A C A B_{i t-1}+\beta_{1} A I D_{i t}+\sum_{k=1}^{K} \delta_{1 k} X_{k i t}+\varepsilon_{1 i t} \\
& N A G O B_{i t}=\alpha_{2 i}+\rho_{2} N A G O B_{i t-1}+\beta_{2} A I D_{i t}+\sum_{k=1}^{K} \delta_{2 k} X_{k i t}+\varepsilon_{2 i t}
\end{aligned}
$$

where NACAB, NAGOB and AID are all measured in percent of GDP; $\alpha_{1 i}$ and $\alpha_{2 i}$ are unobserved country-specific fixed effects; and $X_{k i t}$ is a vector of control variables of size K. Common controls for both regressions include the variance of aid over the reference period, average per capita income over the period, and an index of autocracy. Additionally, in equation (1) we control for the terms of trade, and in equation (2) we control for the rate of inflation. These variables are, of course, likely to be endogenous; we account for this in our estimation strategy as described below.

The parameters of interest are $\beta_{1}, \beta_{2}, \rho_{1}$ and $\rho_{2}$. Short-run absorption and spending are measured by $\beta_{1}$ and $\beta_{2}$ respectively, while $\rho_{1}$ and $\rho_{2}$ are measures of the level of persistence in the non-aid current account balance and the non-aid fiscal balance. Long-run absorption and spending are given by $\frac{\beta_{1}}{1-\rho_{1}}$ and $\frac{\beta_{2}}{1-\rho_{2}}$ respectively. Our priors are that $\beta_{1}<0, \beta_{2}<0,0<\rho_{1}<1$, and $0<\rho_{2}<1$, i.e. that in the presence of absorption and spending the non-aid current account balance and the non-aid fiscal balance fall with every additional dollar of aid in both the short-run and the long-run.

Equations (1) and (2) cannot be consistently estimated using OLS, because of the presence of a lagged dependent term on the right-hand side. To address this problem and the potential endogeneity of the other regressors, we use an application of the generalized method of moments (GMM) - the so-called system estimator — suggested by Blundell and Bond (1998). ${ }^{12}$ This entails utilizing a system of equations - the levels equations above and the equations in first differences - for estimation. The equations differ in their moment conditions and hence in the set of instruments used. Predetermined and endogenous variables in first differences are instrumented with lags of their own levels, while predetermined and endogenous variables in levels are instrumented with lags of their own first differences. We also employ the GMM difference estimator and the fixed effects estimator to check the sensitivity of our results to different methodologies; these checks are detailed in the Section V.

\footnotetext{
12 Blundell and Bond's system estimator is an extension of the earlier difference estimator suggested by Arellano and Bond (1991) and popularized in the growth literature by Caselli, Esquivel and Lefort (1996).
} 
System GMM produces consistent parameter estimates provided that the dependent variable is mean stationary and that the unobserved country effects are uncorrelated with changes in the error term, i.e. that $E\left[\alpha_{1 i} D \varepsilon_{1 i t}\right]=0$ and $E\left[\alpha_{2 i} D \varepsilon_{2 i t}\right]=0$.

$\mathrm{AR}(1)$ is expected in first differences because of the correlation between $D \varepsilon_{1 i t}$ and $D \varepsilon_{1 i t-1}$, and between $D \varepsilon_{2 i t}$ and $D \varepsilon_{2 i t-1}$. But higher-order serial correlation would indicate that some lags of the dependent variable - which may be used as instruments - are in fact endogenous and hence bad instruments. We check these moment conditions when we turn to the regression results in the next section. Table 2 presents stationarity tests for the dependent variables; all the results confirm that the variables are stationary.

After estimating our main absorption and spending equations, we apply the same econometric methodology to two related issues. First, we estimate the impact of aid on reserve accumulation. Aid dollars that are not absorbed must be used to bolster reserves or must exit the country through the capital account. To find out which, we specify the following regression:

$$
\Delta R_{i t}=\alpha_{3 i}+\rho_{3} \Delta R_{i t-1}+\beta_{3} A I D_{i t}+\sum_{k=1}^{K} \delta_{3 k} X_{k i t}+\varepsilon_{3 i t}
$$

We use the same control variables as in regression (3.1). Provided that some aid is initially used to bolster reserve accumulation, we would expect that $\beta_{3} \geq 0$. Moreover, $1-\left|\beta_{1}\right|+\left|\beta_{3}\right|$ provides an estimate of the impact of aid on the capital account, given the balance of payments identity (2.2). If some aid is used to bolster reserve accumulation even in the longrun, then $\rho_{3}<1$. In a world of delayed absorption, where some of the aid used to accumulate reserves in the short-run is subsequently drawn down to finance imports, we would expect that the long-run impact of aid on reserve accumulation is less than the short-run impact, i.e. that $\rho_{3}<0$.

Finally, we turn to the question of aid's incremental impact on investment. We specify that:

$$
\Delta I_{i t}=\alpha_{4 i}+\rho_{4} \Delta I_{i t-1}+\beta_{4} A I D_{i t}+\sum_{k=1}^{K} \delta_{4 k} X_{k i t}+\varepsilon_{4 i t}
$$

where I represents investment. Aid that is absorbed must be either invested or consumed, so we expect that $0 \leq\left|\beta_{4}\right| \leq\left|\beta_{1}\right|$. We also investigate the possibility that aid used for public investment crowds-out private investment to some extent, by running (3.4) including and excluding private investment as a control variable. 


\section{Results}

Our key results for absorption are contained in Table 3. All signs are as expected, and moment conditions are satisfied. Column 1 shows that in the short-run about 30 cents out of every aid dollar is absorbed. Long-run absorption depends also on the co-efficient on the lagged non-aid current account balance, which is high and indicates a significant amount of persistence. Thus, successive periods see further absorption. In the long-run, absorption is about 83 cents to the dollar (Figure 1), which is not significantly different from full absorption. ${ }^{13}$ Figure 1 describes the complete time-path of absorption; it takes 7-8 years to asymptote towards the long-run level of absorption. This pattern of delayed absorption is consistent with staggered public investment or public consumption out of aid. For example, aid for a particular infrastructure project may be fully disbursed at time $t$, but the project may take several years to construct, with the aid dollars being used incrementally to finance imports over the construction period.

The results also indicate that per capita GDP and aid volatility have a significant impact on aid recipients' current account balance. A $1 \%$ increase in per capita GDP increases a country's current account balance by $1.3 \%$. Aid volatility has a small but significant negative impact on the current account balance.

Column 1 of Table 4 presents our main results on spending. In the short-run about 56 cents to the dollar are spent by the fiscal authorities. Note that this is significantly greater than the impact on absorption. In the long-run about 160 cents per aid dollar are spent, i.e. spending is considerably greater than 100 percent. The difference between absorption and spending does not dissipate, but rather increases in subsequent periods. ${ }^{14}$

This fundamental result - that spending exceeds absorption in both the short- and longruns - implies that aid may generate significant macroeconomic imbalances in recipient economies, as discussed in Section II. The result conforms to the evidence from earlier case studies. Different reasons may govern the divergence of spending and absorption in the shortand long-runs. In the short-run, it is likely that there is incomplete coordination between the fiscal and monetary authorities on using the proceeds from aid. In particular, it may be that the government wishes to immediately commence spending on various projects (this is often a pre-condition for the disbursement of project aid), while the monetary authority resists selling aid dollars because it is concerned that currency appreciation will erode

\footnotetext{
${ }^{13}$ Long-run confidence intervals for parameter estimates are calculated using the delta method. The nonlinearity of the long-run point estimates implies a loss of precision.

${ }^{14}$ Strictly speaking, the difference in the point estimate increases over time. Due to a loss of precision in estimating long-run parameters, the confidence intervals on absorption and spending also widen over time. Nonetheless, long-run spending is greater than long-run absorption at an 80 percent confidence level.
} 
competitiveness (IMF 2005). In the long-run, spending exceeds 100\%. One plausible explanation for this is that certain aid-financed capital expenditures create the need for additional recurrent expenditures in each successive period. For example an aid-financed school may require recurrent public expenditure on teachers and school supplies, or a road may need recurrent maintenance and repair. The sum total of the initial capital expenditure and the subsequent recurrent expenditures on the project may exceed the amount of aid.

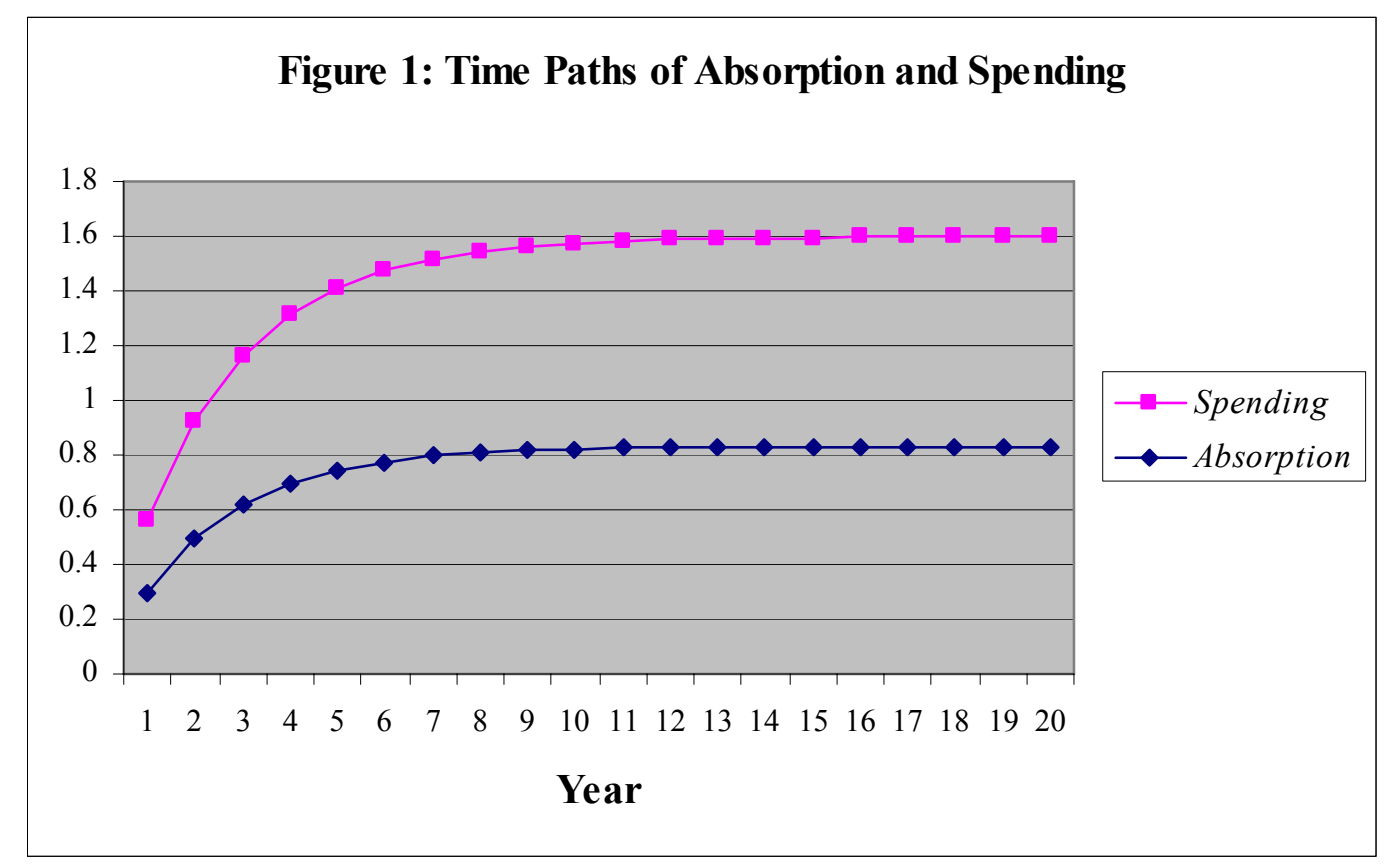

Given that absorption is incomplete in the short-run, what happens to unabsorbed aid? Column 1 of Table 5 presents the results from equation (3.3). The impact of aid on reserve accumulation in the short-run is close to zero and insignificant. So is the long-run impact. Identity (2.2) implies, therefore, that in the short-run, much of the unabsorbed aid - almost $70 \%$ - must be exiting the country through the capital account. Over time, however, most of the initial capital outflow is reversed to accommodate delayed absorption. This is consistent with a world in which the central bank sells most of the aid dollars on disbursement. However, the agents who buy these dollars initially use them to rebalance their portfolios, switching from domestic assets to foreign currency assets. Over time, these foreign assets are drawn down to finance greater imports. This result suggests that further research into the links between aid flows and capital account flows may be critical to assessing the impact of aid.

Both absorption and spending display "smoothing" behavior. While aid is largely absorbed and more than fully spent in the long run, in the short run much of it is saved. This is consistent with forward-looking behavior that seeks insurance against shocks to aid flows in the future. However, note that, at least on the absorption side, the smoothing is not achieved in a standard manner. A textbook smoothing mechanism would be to build international reserves when aid flows are received, and run them down as projects are implemented over time. The pattern observed here, however, is more consistent with smoothing by the private 
sector. The central bank sells most aid dollars on receipt. But the private agents who purchase these dollars do not use them to finance imports immediately. Rather, the dollars are initially saved (and hence not absorbed) in the short-run, and only used at a horizon of five years or longer.

Our final exercise is to directly examine aid's impact on investment. Absorbed aid must be either invested or consumed, but whatever the welfare consequences of this division, presumably what matters more for economic growth is the amount invested. Column 1 of Table 6 contains the results of equation (3.4). In the short run, an increase of $1 \%$ of GDP in aid leads to an increase in gross capital formation of about .14\% of GDP, that is, close to half of absorbed aid goes toward investment. In the long run gross capital formation due to aid increases slowly to about .26\% of GDP, well under the long-run absorption level.

Moreover, we find evidence that the public investment engendered by aid has a crowding-out effect on private investment. This may be seen by comparing Table 6 with and Table 7. Private investment, by definition, exerts an independent influence on the total level of investment, and hence is included as a control variable in Table 6. However, in the presence of crowding-out, we would expect that a regression without private investment as a control would show a reduced impact of aid on total investment. This is indeed the case, as shown in Column 1 of Table 7. Without including private investment as a control, the point estimate of the impact of aid on investment becomes small and insignificant.

Through what channel does this crowding-out occur? This is an area of sufficient importance to command its own research agenda, and is not directly pursued in this paper. However, an obvious link to the results on spending and absorption is worth emphasizing. Since spending systematically exceeds absorption, aid recipients face an incipient increase in money supply, which can either be accommodated or sterilized via a hike in interest rates (e.g. through greater issuance of government paper). The crowding-out of private investment is clearly consistent with the latter response. 
Summary of Main Empirical Results

\begin{tabular}{|l|c|c|}
\hline \multicolumn{3}{|c|}{ Percentage Impact of a 1\% Increase in Aid } \\
\hline & Short Run & Long Run \\
\hline Absorption & $.30^{* * *}$ & $.83^{\star *}$ \\
& $(.08)$ & $(.32)$ \\
\hline Spending & $.56^{* * *}$ & $1.60^{* *}$ \\
& $(.07)$ & $(.27)$ \\
\hline Reserves Accumulation & .05 & .05 \\
& $(1.24)$ & $(2.40)$ \\
\hline Investment & $.14^{* * *}$ & $.26^{* * *}$ \\
& $(.03)$ & $(.059)$ \\
\hline
\end{tabular}

${ }^{1}$ Standard deviation in parentheses. ** indicates significance at the $5 \%$ level. $* * *$ indicates significance at the $1 \%$ level.

Tables 3 through 7 also include absorption, spending, reserve accumulation and investment specifications for three regional sub-samples-African countries (AFR), Latin America and the Caribbean (LAC), and other countries (OC) - of the dataset. Due to the much smaller sample sizes, there is considerable loss of precision in the estimates, but qualitatively the story is similar for each of the three regions. There are, however, some interesting differences. Absorption is slightly higher than the mean for the AFR and OC sub-samples, while it is considerably lower in the LAC sub-sample (Columns 2 through 4 of Table 3). The pattern is similar for spending, with spending being the highest in AFR, while OC is close to the estimate for the full sample, and LAC is considerably lower (Columns 2 through 4 of Table 4). Turning to the impact of aid on reserve accumulation, we find that in AFR (as for the whole sample), the impact is negligible and insignificant; however, there is a significant albeit small effect on reserve accumulation in both LAC and OC (Columns 2 through 4 of Table 5). Moreover, the positive impact on reserve accumulation appears to be permanent, not temporary, in these two regions. Finally, Table 6 documents that the impact of aid on investment is greatest in AFR, considerably lower in OC, and negligible and insignificant in LAC.

\section{ROBUSTNESS OF THE ESTIMATES}

In this section we perform three robustness tests: we run the regressions of the previous section using alternative dynamic panel estimation strategies; using only the most recent decade of data; and using a restricted sample comprising economies that received large amounts of aid.

There is a large literature on the appropriate usage of GMM estimators for dynamic panels. ${ }^{15}$ In the previous section we used the Blundell-Bond system estimator to document our main

\footnotetext{
${ }^{15}$ Bond (2002) and Judson and Owen (1999) contain useful surveys.
} 
results. The system estimator has several advantages over other identification strategies, including applicability to unbalanced panels (unlike a bias-corrected fixed effects estimator) and time-invariant regressors (unlike the Arellano-Bond difference estimator). But for completeness we also estimate the basic regressions for absorption, spending and investment using the difference estimator and the fixed effects estimator. As the table below shows, the results from these three alternative methodologies are qualitatively identical to each other and, indeed, very close quantitatively. The most notable quantitative difference from the baseline results is that long-run investment out of aid is estimated as lower using the difference and fixed effects estimator.

\section{Alternative Estimation Methodologies}

\begin{tabular}{|c|l|c|c|c|}
\hline \multicolumn{2}{|c|}{} & \multicolumn{3}{|c|}{ Type of Estimator $^{1}$} \\
\cline { 3 - 5 } \multirow{2}{*}{ Absorption } & Short Run & System & Difference & Fixed Effects \\
\cline { 2 - 5 } & Long Run & $.31(.08)^{* * *}$ & $.31(.10)^{* *}$ & $.38(.03)^{* * *}$ \\
\hline \multirow{2}{*}{ Spending } & Short Run & $.85(.32)^{* *}$ & $.70(.25)^{* * *}$ & $.92(.08)^{* * *}$ \\
\cline { 2 - 5 } & Long Run & $.56(.07)^{* * *}$ & $.75(.12)^{* * *}$ & $.66(.05)^{* * *}$ \\
\hline \multirow{2}{*}{ Investment } & Short Run & $.59(.27)^{* * *}$ & $1.66(.39)^{* * *}$ & $1.44(.10)^{* * *}$ \\
\cline { 2 - 5 } & Long Run & $.14(.03)^{* * *}$ & $.11(.03)^{* * *}$ & $.11(.01)^{* * *}$ \\
\hline
\end{tabular}

${ }^{1}$ Standard deviation in parentheses. $* *$ indicates significance at the $5 \%$ level. $* * *$ indicates significance at the $1 \%$ level.

Next we turn to a more recent sub-sample of the data, examining the period 1994-2004. The data for this most recent decade is the most complete in the sense of including the largest number of countries and having less missing data for individual years. Tables 8 through 11 show that our main qualitative conclusions remain unaltered. Although absorption is found to be somewhat higher than in Section IV, it remains incomplete in the short run and picks-up over time. Spending is greater than absorption, and aid has a negligible impact on reserve accumulation. Aid's impact on investment is again relatively small, with most of absorbed aid not going toward investment. Absorption and spending are higher for AFR than for the other countries in the sample.

Would our results be different if we restricted the sample to large aid recipients? Tables 12 and 13 present results on absorption and spending for countries that received more than 2 percent, 5 percent and 10 percent of GDP as aid over the 1970-2004 period. There are 49 countries in our sample for which the aid-to-GDP ratio is larger than 2 percent. In these countries the short- and long-run rates of absorption are 34 percent and 87 percent respectively. For the 35 countries that received aid of over 5 percent of GDP the absorption rates are 36 percent and 92 percent. For the 18 countries that received aid of over 10 percent of GDP the absorption rates are 45 percent and 110 percent. Thus there is a tendency for absorption to increase with aid. The trend is similar for spending. The short- and long-run spending rates for countries with aid-to-GDP ratios higher than 2 percent, 5 percent and 10 percent are, respectively, 55 percent and 160 percent, 58 percent and 160 percent, and 68 percent and 180 percent. 
The impact of aid on reserve accumulation and investment for large aid-recipients is examined in Tables 14 and 15. The results are again in accord with the previous section. Aid has no significant impact on reserve accumulation. Moreover, less than half of absorbed aid goes into investment. The investment propensity of aid is between 40 and 50 percent of the absorption rate in the short-run, and under a third of the absorption rate in the long-run; exactly as before.

Finally, our results are robust to several changes in lag structure, and to using three-year averages of the data series. We do not show these results here, but can make them available to the interested reader.

\section{CONCLuSION}

The nominal flow of aid dollars from donors to recipients does not measure the actual transfer of resources. The real transfer is captured by absorbed aid. Moreover, aid spending can differ from aid absorption, which can have a variety of macroeconomic consequences depending on how exactly the two differ.

This paper attempts to systematize the data on aid and provide some stylized facts on the macroeconomic usage of aid, thus going an important step beyond the case study approach of IMF (2005) and Berg et al (2007). We find that absorption is typically low in the short-run, and but picks up substantially over time. Spending is greater than absorption in both the short- and the long-run. This implies that aid systematically engenders an injection of domestic liquidity into recipient economies. Absent a countervailing rise in the demand for money, this would lead to higher inflation and / or higher interest rates due to sterilization.

We find that aid has a negligible impact on reserve accumulation, implying that incomplete absorption in the short-run is accompanied by some of the aid leaving the recipient country through capital outflows (and returning via capital inflows as absorption increases over time). Thus, while there appears to be "smoothing" behavior associated with aid inflows, the smoothing is implemented by private agents rather than by the central bank. This finding suggests that more research into the links between aid and the capital account would be fruitful.

Aid's impact on investment is found to be relatively low. Less than half of absorbed aid is devoted to investment in the short-run, and the proportion declines further over the long-run. Moreover, the public investment enabled by aid appears to crowd-out private investment, further lessening the potential impact of aid on growth.

Taken together, the findings of this paper- lags in absorption, macroeconomic problems arising from the excess of spending over absorption, a limited amount of absorbed aid going toward investment, and the crowding-out of private investment - may help illuminate the ambiguous relationship between aid and growth found in the literature.

Subject to the standard warnings about drawing policy conclusions from cross-country regressions, the results presented here would indicate that more careful coordination between 
fiscal and monetary authorities in response to aid inflows is needed. A more coordinated response would seek to keep spending in line with absorption — not necessarily at every point in time, but at least over a reasonable time horizon. Such a response would help avoid an unplanned injection of liquidity into the economy. By eliminating the need to sterilize aid via domestic channels, a coordinated response may reduce the crowding-out of private investment. At a more microeconomic level, the results in this paper indicate at least two criteria - among many others, of course - that could be used in the selection of public projects to be financed through aid: import content, and complementarities with private investment. 
Table 1: Summary Statistics of Main Variables ${ }^{1}$

\begin{tabular}{|c|c|c|c|c|c|c|c|c|}
\hline & \multicolumn{2}{|c|}{ All Countries } & \multicolumn{2}{|c|}{ Africa (AFR) } & \multicolumn{2}{|c|}{$\begin{array}{l}\text { Latin America and } \\
\text { Caribbean (LAC) }\end{array}$} & \multicolumn{2}{|c|}{$\begin{array}{l}\text { Other Countries } \\
\text { (OC) }\end{array}$} \\
\hline & Mean & SE & Mean & SE & Mean & SE & Mean & SE \\
\hline Aid/GDP & 6.80 & 9.36 & 9.79 & 11.11 & 2.65 & 4.41 & 4.95 & 6.96 \\
\hline NACAB/GDP & -10.21 & 16.55 & -14.84 & 19.51 & -3.36 & 8.33 & -7.80 & 13.31 \\
\hline NAGOB/GDP & -19.49 & 250.25 & -29.76 & 360.42 & -7.50 & 5.64 & -11.70 & 11.41 \\
\hline$\Delta R / G D P$ & 0.39 & 3.60 & 0.36 & 3.83 & 0.27 & 2.72 & 0.52 & 3.82 \\
\hline I/GDP & 21.36 & 8.63 & 20.31 & 10.34 & 19.48 & 4.74 & 24.22 & 7.27 \\
\hline Private I/GDP & 13.38 & 7.71 & 12.38 & 9.23 & 13.71 & 5.09 & 14.87 & 6.15 \\
\hline
\end{tabular}

${ }^{1}$ All variables are in \%. Investment is measured as Gross Fixed Capital Formation, while Private Investment is measured as Private Gross Fixed Capital Formation.

Table 2: Stationarity of Main Variables ${ }^{1}$

\begin{tabular}{lrrrr} 
& Aid/GDP & NACAB/GDP & NAGOB/GDP* & GDP ${ }^{1}$ \\
\hline Levin-Lin Rho-Statistic & & & - & -12.90 \\
Levin-Lin t-Rho-Statistic & -88.35 & -84.75 & - & -4.42 \\
Levin-Lin ADF-Statistic & -28.14 & -28.85 & - & -4.82 \\
IPS ADF-Statistic & -25.12 & -22.45 & - & -7.50
\end{tabular}

\footnotetext{
${ }^{1}$ The underlying null hypothesis is that the variables are stationary. Positive values of the statistics above reject the null (implying a unit root), while large negative values support stationarity.

* We use WINRATS to determine stationarity of the unbalanced panel data. Of the variables above, data on the government fiscal deficit are the most irregular, and WINRATS could not perform the test of stationarity for this variable.
} 
Table 3: Aid Absorption ${ }^{1}$

\begin{tabular}{|c|c|c|c|c|}
\hline & $\begin{array}{c}\text { NACAB/GDP } \\
\text { (Full } \\
\text { Sample) } \\
\end{array}$ & $\begin{array}{c}\text { NACAB/GDP } \\
\text { (AFR) }\end{array}$ & $\begin{array}{c}\text { NACAB/GDP } \\
\text { (LAC) }\end{array}$ & $\begin{array}{c}\text { NACAB/GDP } \\
(O C)\end{array}$ \\
\hline L. NACAB/GDP & $\begin{array}{c}0.642 \\
(0.063)\end{array}$ & $\begin{array}{c}0.631 \\
(0.058)^{\star \star \star}\end{array}$ & $\begin{array}{c}0.771 \\
(0.066)\end{array}$ & $\begin{array}{c}0.61 \\
(0.08)\end{array}$ \\
\hline Aid/GDP & $\begin{array}{l}-0.305 \\
(0.080)\end{array}$ & $\begin{array}{l}-0.406 \\
(0.081)^{\star * *}\end{array}$ & $\begin{array}{l}-0.094 \\
(0.050)^{*}\end{array}$ & $\begin{array}{r}-(0.45) \\
(0.12)\end{array}$ \\
\hline Terms of Trade Index & $\begin{array}{l}-0.202 \\
(1.208)\end{array}$ & $\begin{array}{c}1.089 \\
(1.131)\end{array}$ & $\begin{array}{l}-0.402 \\
(0.872)\end{array}$ & $\begin{array}{l}-1.03 \\
(0.46)\end{array}$ \\
\hline Mean GDP per capita & $\begin{array}{c}1.339 \\
(0.581)^{* *}\end{array}$ & $\begin{array}{c}1.174 \\
(0.631)^{*}\end{array}$ & $\begin{array}{l}0.585 \\
(0.617)\end{array}$ & $\begin{array}{l}0.56 \\
(0.17)\end{array}$ \\
\hline $\begin{array}{l}\text { Index of } \\
\text { Autocracy/Democracy }\end{array}$ & -0.009 & -0.044 & -0.038 & -0.008 \\
\hline Volatility of Aid & $\begin{array}{l}(0.060) \\
-0.35 \\
(0.09)\end{array}$ & $\begin{array}{l}(0.079) \\
-0.36 \\
(0.106)^{\star \star *}\end{array}$ & $\begin{array}{c}(0.039) \\
0.08 \\
(0.09)\end{array}$ & $\begin{array}{l}(0.02) \\
-0.1 \\
(0.049)\end{array}$ \\
\hline Observations & 2218 & 1087 & 594 & 537 \\
\hline Number of Countries & 72 & 37 & 18 & 17 \\
\hline $\begin{array}{l}\text { Arellano-Bond test for } \\
A R(1)\end{array}$ & -3.00 & -2.29 & -2.86 & -2.50 \\
\hline $\begin{array}{l}\text { Arellano-Bond test for } \\
A R(2)\end{array}$ & -0.20 & 0.04 & -0.44 & -1.07 \\
\hline $\begin{array}{l}\text { Hansen test of over-id } \\
\text { restrictions }\end{array}$ & 42.03 & 3.43 & 0 & 0.00 \\
\hline Prob $>$ Chi2 & 1 & 1 & 1 & 1 \\
\hline
\end{tabular}


Table 4: Aid Spending ${ }^{1}$

$\begin{array}{lccc}\text { NAGOB/GDP } & \text { NAGOB/GDP } & \text { NAGOB/GDP } & \text { NAGOB/GDP } \\ \text { (Full Sample) } & \text { (AFR) } & \text { (LAC) } & \text { (OC) }\end{array}$

\begin{tabular}{|c|c|c|c|c|}
\hline L. NAGOB/GDP & $\begin{array}{l}0.65 \\
(0.029)\end{array}$ & $\begin{array}{l}0.62 \\
(0.021)\end{array}$ & $\begin{array}{l}0.68 \\
(0.040)\end{array}$ & $\begin{array}{c}0.63 \\
(0.09)\end{array}$ \\
\hline Aid/GDP & $\begin{array}{l}-0.56 \\
(0.071)\end{array}$ & $\begin{array}{l}-0.79 \\
(0.172)\end{array}$ & $\begin{array}{l}-0.35 \\
(0.091)\end{array}$ & $\begin{array}{l}-0.51 \\
(0.16)\end{array}$ \\
\hline Mean GDP per capita & $\begin{array}{l}-1.63 \\
(0.604)\end{array}$ & $\begin{array}{l}-1.72 \\
(1.585)\end{array}$ & $\begin{array}{l}-1.21 \\
(0.395)\end{array}$ & $\begin{array}{c}0.46 \\
(0.38)\end{array}$ \\
\hline Index of Autocracy/Democracy & $\begin{array}{l}0.04 \\
(0.056)\end{array}$ & $\begin{array}{l}0.41 \\
(0.145)\end{array}$ & $\begin{array}{l}0.03 \\
(0.042)\end{array}$ & $\begin{array}{r}0.001 \\
(0.03)\end{array}$ \\
\hline Volatility of Aid & $\begin{array}{l}-0.016 \\
(0.08)\end{array}$ & $\begin{array}{l}0.13 \\
(0.14)\end{array}$ & $\begin{array}{l}-0.15 \\
(0.11)\end{array}$ & $\begin{array}{l}-0.06 \\
(0.12)\end{array}$ \\
\hline Inflation & $\begin{array}{l}-0.29 \\
(0.337)\end{array}$ & $\begin{array}{l}-0.91 \\
(0.537)^{*}\end{array}$ & $\begin{array}{c}0.08 \\
(0.21)\end{array}$ & $\begin{array}{c}0.06 \\
(0.19)\end{array}$ \\
\hline Observations & 1290 & 539 & 388 & 363 \\
\hline Number of Countries & 62 & 31 & 16 & 15 \\
\hline Arellano-Bond test for $A R(1)$ & -3.09 & -2.27 & -2.96 & -2.46 \\
\hline 'Arellano-Bond test for AR(2) & -1.04 & -1.05 & -1.20 & -0.53 \\
\hline $\begin{array}{l}\text { Hansen test of over-id } \\
\text { restrictions }\end{array}$ & 26.96 & 3.81 & 0 & 0.00 \\
\hline Prob $>$ Chi2 & 1 & 1 & 1 & 1 \\
\hline
\end{tabular}


Table 5: Reserve Accumulation Out of Aid ${ }^{1}$

\begin{tabular}{|c|c|c|c|c|}
\hline & $\begin{array}{c}\Delta R / G D P \\
\text { (Full } \\
\text { Sample) }\end{array}$ & $\begin{array}{l}\Delta R / G D P \\
\text { (AFR) }\end{array}$ & $\begin{array}{l}\Delta R / G D P \\
(\text { LAC) }\end{array}$ & $\begin{array}{l}\Delta R / G D P \\
\text { (OC) }\end{array}$ \\
\hline L. $\Delta R / G D P$ & $\begin{array}{c}0.021 \\
(0.27)\end{array}$ & $\begin{array}{c}0.035 \\
(0.35)\end{array}$ & $\begin{array}{c}0.102 \\
(0.76)\end{array}$ & $\begin{array}{l}-0.005 \\
(0.11)\end{array}$ \\
\hline Aid/GDP & $\begin{array}{l}0.052 \\
(1.24)\end{array}$ & $\begin{array}{l}0.010 \\
(0.34)\end{array}$ & $\begin{array}{l}0.060 \\
(2.02)\end{array}$ & $\begin{array}{l}0.190 \\
(2.48)\end{array}$ \\
\hline Terms of Trade Index & $\begin{array}{l}0.537 \\
(1.44)\end{array}$ & $\begin{array}{l}0.609 \\
1.78)^{*}\end{array}$ & $\begin{array}{l}0.264 \\
(0.49)\end{array}$ & $\begin{array}{l}0.000 \\
(0.00)\end{array}$ \\
\hline Mean GDP per capita & $\begin{array}{l}0.365 \\
(1.46)\end{array}$ & $\begin{array}{c}0.524 \\
(1.95)^{\star}\end{array}$ & $\begin{array}{l}0.222 \\
(2.26)\end{array}$ & $\begin{array}{c}0.224 \\
(1.57)\end{array}$ \\
\hline Index of Autocracy/Democracy & $\begin{array}{l}-0.018 \\
(0.58)\end{array}$ & $\begin{array}{r}0.041 \\
(1.63)\end{array}$ & $\begin{array}{l}0.001 \\
(0.05)\end{array}$ & $\begin{array}{l}-0.016 \\
(1.07)\end{array}$ \\
\hline Volatility of Aid & $\begin{array}{l}-0.047 \\
(0.83)\end{array}$ & $\begin{array}{l}0.010 \\
(0.36)\end{array}$ & $\begin{array}{l}-0.054 \\
(1.94)\end{array}$ & $\begin{array}{l}-0.236 \\
(3.11)\end{array}$ \\
\hline Observations & 2073 & 1007 & 576 & 490 \\
\hline Number of Countries & 72 & 37 & 18 & 17 \\
\hline Arellano-Bond test for AR(1) & -3.80 & -2.70 & -2.91 & -2.77 \\
\hline Arellano-Bond test for AR(2) & -0.03 & 0.65 & -0.37 & -1.43 \\
\hline $\begin{array}{l}\text { Hansen test of over-id } \\
\text { restrictions }\end{array}$ & 35.07 & 3.22 & 0.00 & 0.00 \\
\hline Prob $>$ Chi2 & 1 & 1 & 1 & 1 \\
\hline
\end{tabular}


Table 6: Impact of Aid on Investment ${ }^{1}$

\begin{tabular}{|c|c|c|c|c|}
\hline & $\begin{array}{c}\text { I/GDP } \\
\text { (Full Sample) }\end{array}$ & $\begin{array}{l}\text { I/GDP } \\
\text { (AFR) }\end{array}$ & $\begin{array}{l}\text { I/GDP } \\
\text { (LAC) }\end{array}$ & $\begin{array}{l}\text { I/GDP } \\
\text { (OC) }\end{array}$ \\
\hline L. I/GDP & $\begin{array}{c}0.476 \\
(0.106)\end{array}$ & $\begin{array}{c}0.426 \\
(0.113)\end{array}$ & $\begin{array}{c}0.634 \\
(0.051)^{\star * *}\end{array}$ & $\begin{array}{l}0.72 \\
(0.05)^{\star * *}\end{array}$ \\
\hline Aid/GDP & $\begin{array}{c}0.135 \\
(0.034)\end{array}$ & $\begin{array}{c}0.148 \\
(0.049)\end{array}$ & $\begin{array}{c}0.021 \\
(0.044)\end{array}$ & $\begin{array}{l}0.08 \\
(0.03)^{\star *}\end{array}$ \\
\hline Mean GDP per capita & $\begin{array}{c}0.600 \\
(0.382)\end{array}$ & $\begin{array}{c}0.394 \\
(0.507)\end{array}$ & $\begin{array}{l}-0.491 \\
(0.316)\end{array}$ & $\begin{array}{c}0.2 \\
(0.25)\end{array}$ \\
\hline Terms of Trade Index & $\begin{array}{l}-1.789 \\
(0.737)\end{array}$ & $\begin{array}{l}-1.700 \\
(0.920)\end{array}$ & $\begin{array}{l}-1.367 \\
(0.900)\end{array}$ & $\begin{array}{l}-0.28 \\
(0.48\end{array}$ \\
\hline Index of Autocracy/Democracy & $\begin{array}{l}-0.010 \\
(0.040)\end{array}$ & $\begin{array}{c}0.078 \\
(0.049)\end{array}$ & $\begin{array}{c}0.106 \\
(0.036)^{\star * *}\end{array}$ & $\begin{array}{l}-0.08 \\
(0.03)\end{array}$ \\
\hline Volatility of Aid & $\begin{array}{c}0.204 \\
(0.075)\end{array}$ & $\begin{array}{c}0.227 \\
(0.079)\end{array}$ & $\begin{array}{c}0.014 \\
(0.050)\end{array}$ & $\begin{array}{l}-0.09 \\
(0.06)\end{array}$ \\
\hline Private I/GDP & $\begin{array}{c}0.540 \\
(0.091)\end{array}$ & $\begin{array}{c}0.598 \\
(0.094)^{\star * *}\end{array}$ & $\begin{array}{c}0.345 \\
(0.060)^{\star * *}\end{array}$ & $\begin{array}{l}0.3 \\
(0.04)^{* * *}\end{array}$ \\
\hline Observations & 1813 & 888 & 497 & 428 \\
\hline Number of Countries & 72 & 37 & 18 & 17 \\
\hline Arellano-Bond test for $A R(1)$ & -3.59 & -2.83 & -3.46 & -3.01 \\
\hline Arellano-Bond test for AR(2) & 0.27 & 0.89 & -2.06 & -1.68 \\
\hline Hansen test of over-id restrictions & 25.72 & 0.82 & 0.00 & 0.00 \\
\hline Prob $>$ Chi2 & 1 & 1 & 1 & 1 \\
\hline
\end{tabular}


Table 7: Impact of Aid on Investment ${ }^{12}$

\begin{tabular}{|c|c|c|c|c|}
\hline & $\begin{array}{c}\text { I/GDP } \\
\text { (Full Sample) }\end{array}$ & $\begin{array}{l}\text { I/GDP } \\
\text { (AFR) }\end{array}$ & $\begin{array}{l}\text { I/GDP } \\
\text { (LAC) }\end{array}$ & $\begin{array}{c}\text { I/GDP } \\
(O C)\end{array}$ \\
\hline L. I/GDP & $\begin{array}{c}0.805 \\
(0.047)^{\star \star \star}\end{array}$ & $\begin{array}{l}0.832 \\
(0.059)^{\star * *}\end{array}$ & $\begin{array}{c}0.819 \\
(0.030)^{\star * *}\end{array}$ & $\begin{array}{l}0.85 \\
(0.03)^{\star * *}\end{array}$ \\
\hline Aid to GDP & $\begin{array}{c}0.021 \\
(0.058)\end{array}$ & $\begin{array}{c}0.003 \\
(0.053)\end{array}$ & $\begin{array}{l}-0.015 \\
(0.030)\end{array}$ & $\begin{array}{l}0.13 \\
(0.04)^{* * *}\end{array}$ \\
\hline Mean GDP per capita & $\begin{array}{c}1.141 \\
(0.376)^{* * *}\end{array}$ & $\begin{array}{l}1.267 \\
(0.607)^{* *}\end{array}$ & $\begin{array}{l}-0.117 \\
(0.258)\end{array}$ & $\begin{array}{c}0.4 \\
(0.25)\end{array}$ \\
\hline Terms of Trade Index & $\begin{array}{l}-2.783 \\
(1.456)^{*}\end{array}$ & $\begin{array}{l}-2.637 \\
(1.342)^{* *}\end{array}$ & $\begin{array}{l}-0.902 \\
(0.592)\end{array}$ & $\begin{array}{l}0.47 \\
(0.26)^{*}\end{array}$ \\
\hline Index of Autocracy/Democracy & $\begin{array}{l}-0.043 \\
(0.050)\end{array}$ & $\begin{array}{l}-0.051 \\
(0.063)\end{array}$ & $\begin{array}{c}0.037 \\
(0.022)^{*}\end{array}$ & $\begin{array}{l}-0.04 \\
(0.018)\end{array}$ \\
\hline Volatility of Aid & $\begin{array}{c}0.294 \\
(0.201)\end{array}$ & $\begin{array}{c}0.295 \\
(0.220)\end{array}$ & $\begin{array}{c}0.044 \\
(0.048)\end{array}$ & $\begin{array}{l}-0.16 \\
(0.03)^{* * *}\end{array}$ \\
\hline Observations & 2047 & 967 & 571 & 509 \\
\hline Number of Countries & 72 & 37 & 18 & 17 \\
\hline Arellano-Bond test for $A R(1)$ & -2.40 & -2.03 & -3.56 & -3.08 \\
\hline Arellano-Bond test for AR(2) & -0.01 & 0.53 & -2.68 & -2.48 \\
\hline Hansen test of over-id restrictions & 32.46 & 3.11 & 0.00 & 0.00 \\
\hline Prob $>$ Chi2 & 1 & 1 & 1 & 1 \\
\hline
\end{tabular}


Table 8: Aid Absorption 1994-2004

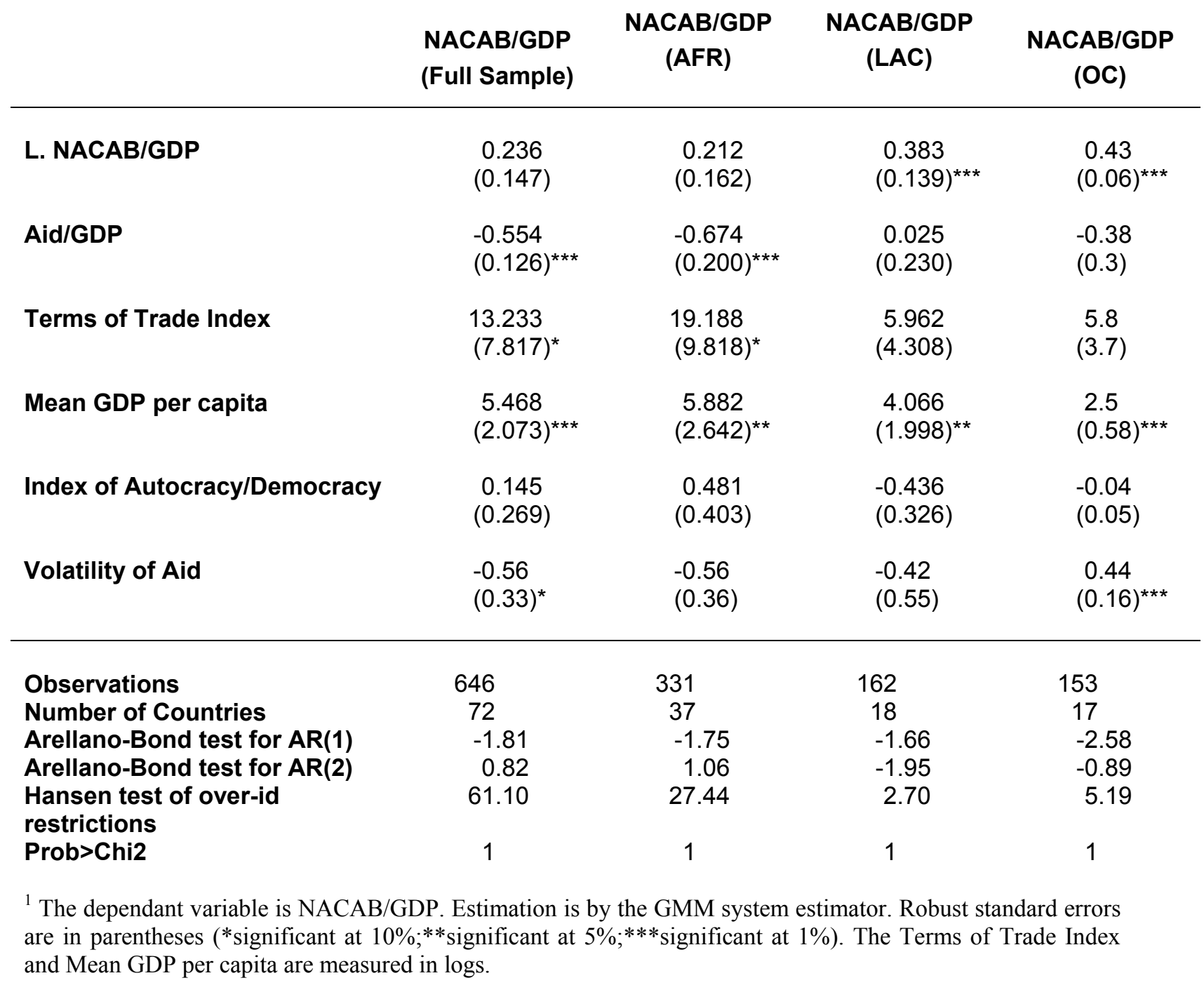


Table 9: Aid Spending 1994-2004

$\begin{array}{llll}\text { NAGOB/GDP } & \text { NAGOB/GDP } & \text { NAGOB/GDP } & \text { NAGOB/GDP } \\ \text { (Full Sample) } & \text { (AFR) } & \text { (LAC) } & \text { (OC) }\end{array}$

\begin{tabular}{|c|c|c|c|c|}
\hline L. NAGOB/GDP & $\begin{array}{l}0.212 \\
(0.074)^{* * *}\end{array}$ & $\begin{array}{c}0.051 \\
(0.056)\end{array}$ & $\begin{array}{l}0.609 \\
(0.101)^{* * *}\end{array}$ & $\begin{array}{l}0.26 \\
(0.04)^{* * *}\end{array}$ \\
\hline Aid/GDP & $\begin{array}{l}-0.775 \\
(0.112)^{\star \star \star}\end{array}$ & $\begin{array}{l}-0.790 \\
(0.153)^{\star \star *}\end{array}$ & $\begin{array}{l}-0.226 \\
(0.123)^{*}\end{array}$ & $\begin{array}{l}-0.89 \\
(0.17)^{\star \star \star}\end{array}$ \\
\hline Mean GDP per capita & $\begin{array}{l}-1.183 \\
(1.010)\end{array}$ & $\begin{array}{l}-0.959 \\
(1.628)\end{array}$ & $\begin{array}{l}-0.962 \\
(0.978)\end{array}$ & $\begin{array}{l}1.55 \\
(0.52)^{* * *}\end{array}$ \\
\hline Index of Autocracy/Democracy & $\begin{array}{c}0.087 \\
(0.094)\end{array}$ & $\begin{array}{l}0.321 \\
(0.171)^{*}\end{array}$ & $\begin{array}{c}0.252 \\
(0.154)\end{array}$ & $\begin{array}{l}-0.15 \\
(0.05)^{\star \star \star}\end{array}$ \\
\hline Volatility of Aid & $\begin{array}{l}-0.39 \\
(0.32)\end{array}$ & $\begin{array}{l}-1.07 \\
(0.41)^{\star * *}\end{array}$ & $\begin{array}{l}-0.14 \\
(0.26)\end{array}$ & $\begin{array}{l}-0.03 \\
(0.14)\end{array}$ \\
\hline Inflation & $\begin{array}{c}0.185 \\
(0.410)\end{array}$ & $\begin{array}{l}-0.485 \\
(0.595)\end{array}$ & $\begin{array}{c}0.551 \\
(0.368)\end{array}$ & $\begin{array}{l}1.00 \\
(0.25)^{* \star *}\end{array}$ \\
\hline Observations & 508 & 236 & 144 & 128 \\
\hline Number of Countries & 61 & 30 & 16 & 15 \\
\hline Arellano-Bond test for AR(1) & -1.91 & -1.54 & -2.23 & 2.55 \\
\hline Arellano-Bond test for AR(2) & -1.42 & -0.89 & -1.43 & -1.81 \\
\hline $\begin{array}{l}\text { Hansen test of over-id } \\
\text { restrictions }\end{array}$ & 54.94 & 11.13 & 1.75 & -1.08 \\
\hline Prob $>$ Chi2 & 1 & 1 & 1 & 1 \\
\hline
\end{tabular}


Table 10: Reserve Accumulation Out of Aid 1994-2004 ${ }^{1}$

\begin{tabular}{lcccc} 
& $\begin{array}{c}\Delta R / G D P \\
\text { (Full } \\
\text { Sample) }\end{array}$ & $\begin{array}{c}\Delta \text { R/GDP } \\
\text { (AFR) }\end{array}$ & $\begin{array}{c}\Delta R / G D P \\
\text { (LAC) }\end{array}$ & $\begin{array}{c}\Delta R / G D P \\
(\text { OC) }\end{array}$ \\
\hline & & & & \\
L. $\Delta$ R/GDP & -0.28 & 0.047 & 0.052 & -0.522 \\
Aid/GDP & $(0.24)$ & $(0.29)$ & $(0.16)$ & $(0.090$ \\
& -0.03 & -0.13 & -0.11 & 0.24 \\
Terms of Trade Index & $(0.08)$ & $(0.09)$ & $(0.24)$ & $(0.17)$ \\
& 4.86 & 4.3 & 6.4 & -5.48 \\
Mean GDP per capita & $(1.9)$ & $(1.99)$ & $(2.3)$ & $(2.46)$ \\
& 1.03 & -0.47 & 0.22 & 0.52 \\
Index of Autocracy/Democracy & $(0.068)$ & $(0.74)$ & $(1.13)$ & $(0.32)$ \\
& -0.13 & -0.12 & 0.07 & -0.11 \\
Volatility of Aid & $(0.11)$ & $(0.16)$ & $(0.15)$ & $(0.08)$ \\
& 0.14 & 0.06 & -0.22 & -0.31 \\
& $(0.11)$ & $(0.12)$ & $(0.17)$ & $(0.13)$ \\
\hline & & & & \\
Observations & & & & \\
Number of Countries & 626 & 329 & 162 & 135 \\
Arellano-Bond test for AR(1) & 70 & 37 & 18 & 15 \\
Arellano-Bond test for AR(2) & -1.79 & -2.23 & -2.17 & -2.67 \\
Hansen test of over-id & -0.75 & 0.24 & -1.32 & -1.33 \\
restrictions & 60.94 & 24.57 & 2.32 & 0.00 \\
Prob>Chi2 & & & & \\
& 1 & 1 & 1 & 1
\end{tabular}

${ }^{1}$ The dependant variable is $\Delta \mathrm{R} /$ GDP. Estimation is by the GMM system estimator. Robust standard errors are in parentheses (*significant at 10\%;**significant at 5\%;***significant at $1 \%$ ). The Terms of Trade Index and Mean GDP per capita are measured in logs. 
Table 11: Impact of Aid on Investment 1994-2004

\begin{tabular}{|c|c|c|c|c|}
\hline & $\begin{array}{c}\text { I/GDP } \\
\text { (Full } \\
\text { Sample) }\end{array}$ & $\begin{array}{l}\text { I/GDP } \\
\text { (AFR) }\end{array}$ & $\begin{array}{l}\text { I/GDP } \\
\text { (LAC) }\end{array}$ & $\begin{array}{l}\text { I/GDP } \\
\text { (OC) }\end{array}$ \\
\hline L. I/GDP & $\begin{array}{l}0.24 \\
(0.12)^{\star *}\end{array}$ & $\begin{array}{c}0.18 \\
(0.1)^{*}\end{array}$ & $\begin{array}{c}0.28 \\
(0.08)^{* * *}\end{array}$ & $\begin{array}{c}0.76 \\
(0.08)^{\star * *}\end{array}$ \\
\hline Aid/GDP & $\begin{array}{l}0.11 \\
(0.05)^{\star *}\end{array}$ & $\begin{array}{c}0.16 \\
(0.04)^{\star * *}\end{array}$ & $\begin{array}{l}-0.07 \\
(0.06)\end{array}$ & $\begin{array}{l}-0.01 \\
(0.09)\end{array}$ \\
\hline Mean GDP per capita & $\begin{array}{c}0.41 \\
(0.57)\end{array}$ & $\begin{array}{l}0.15 \\
(0.58)\end{array}$ & $\begin{array}{l}-1.48 \\
(0.49)^{\star *}\end{array}$ & $\begin{array}{l}-0.47 \\
(0.33)\end{array}$ \\
\hline Terms of Trade Index & $\begin{array}{l}-2.05 \\
(1.5)\end{array}$ & $\begin{array}{l}-0.67 \\
(1.37)\end{array}$ & $\begin{array}{l}-5.51 \\
(2.11)^{* *}\end{array}$ & $\begin{array}{l}-0.82 \\
(1.58)\end{array}$ \\
\hline Index of Autocracy/Democracy & $\begin{array}{l}-0.05 \\
(0.09)\end{array}$ & $\begin{array}{c}0.09 \\
(0.11)\end{array}$ & $\begin{array}{l}-0.107 \\
(0.13)\end{array}$ & $\begin{array}{l}-0.09 \\
(0.04)^{*}\end{array}$ \\
\hline Volatility of Aid & $\begin{array}{c}0.04 \\
(0.13)\end{array}$ & $\begin{array}{l}-0.13 \\
(0.1)\end{array}$ & $\begin{array}{l}-0.23 \\
(0.08)^{* *}\end{array}$ & $\begin{array}{c}0.01 \\
(0.07)\end{array}$ \\
\hline Private I/GDP & $\begin{array}{c}0.78 \\
(0.109)^{\star \star \star}\end{array}$ & $\begin{array}{l}0.89 \\
(0.09)^{\star \star \star}\end{array}$ & $\begin{array}{c}0.61 \\
(0.06)^{\star \star \star}\end{array}$ & $\begin{array}{l}0.28 \\
(0.08)^{\star \star *}\end{array}$ \\
\hline Observations & 633 & 326 & 162 & 145 \\
\hline Number of Countries & 72 & 37 & 18 & 17 \\
\hline Arellano-Bond test for AR(1) & -3.77 & -3.10 & -2.49 & -2.34 \\
\hline Arellano-Bond test for AR(2) & 0.87 & 0.82 & -1.44 & 2.22 \\
\hline $\begin{array}{l}\text { Hansen test of over-id } \\
\text { restrictions }\end{array}$ & 59.59 & 21.31 & 1.68 & 0.32 \\
\hline Prob $>$ Chi2 & 1 & 1 & 1 & 1 \\
\hline
\end{tabular}

${ }^{1}$ The dependant variable is Gross Fixed Capital Formation as a fraction of GDP, denoted I/GDP. Estimation is by the GMM system estimator. Robust standard errors are in parentheses (*significant at $10 \%$;**significant at $5 \% ; * *$ significant at $1 \%$ ). The Terms of Trade Index and Mean GDP per capita are measured in logs. 
Table 12: Aid Absorption in Major Aid Receiving Countries ${ }^{1}$

\begin{tabular}{|c|c|c|c|}
\hline & $\begin{array}{l}\text { NACAB/GDP } \\
\text { Aid/GDP>.02 }\end{array}$ & $\begin{array}{l}\text { NACAB/GDP } \\
\text { Aid/GDP>.05 }\end{array}$ & $\begin{array}{l}\text { NACAB/GDP } \\
\text { Aid/GDP>.1 }\end{array}$ \\
\hline L. NACAB/GDP & $\begin{array}{l}0.615 \\
(8.64)^{\star \star *}\end{array}$ & $\begin{array}{l}0.619 \\
(8.73)^{\star * *}\end{array}$ & $\begin{array}{l}0.595 \\
(7.97)^{\star * *}\end{array}$ \\
\hline Aid/GDP & $\begin{array}{l}-0.345 \\
(4.17)^{\star \star *}\end{array}$ & $\begin{array}{l}-0.363 \\
(4.43)^{\star * *}\end{array}$ & $\begin{array}{l}-0.450 \\
(5.65)^{\star \star *}\end{array}$ \\
\hline Terms of Trade Index & $\begin{array}{l}-0.157 \\
(0.11)\end{array}$ & $\begin{array}{l}-0.071 \\
(0.05)\end{array}$ & $\begin{array}{c}2.281 \\
(1.24)\end{array}$ \\
\hline Mean GDP per capita & $\begin{array}{c}1.339 \\
(2.16)^{* *}\end{array}$ & $\begin{array}{c}1.915 \\
(3.22)^{\star \star \star}\end{array}$ & $\begin{array}{r}2.207 \\
(1.40)\end{array}$ \\
\hline Index of Autocracy/Democracy & $\begin{array}{l}-0.027 \\
(0.31)\end{array}$ & $\begin{array}{l}-0.065 \\
(0.76)\end{array}$ & $\begin{array}{c}0.210 \\
(1.26)\end{array}$ \\
\hline Volatility of Aid & $\begin{array}{l}-0.380 \\
(2.77)^{\star * *}\end{array}$ & $\begin{array}{l}-0.358 \\
(2.20)^{* *}\end{array}$ & $\begin{array}{l}-0.396 \\
(1.99)^{\star *}\end{array}$ \\
\hline Observations & 1518 & 1068 & 535 \\
\hline Number of Countries & 49 & 35 & 18 \\
\hline Arellano-Bond test for $A R(1)$ & -2.75 & -2.55 & -2.08 \\
\hline Arellano-Bond test for $A R(2)$ & 0.38 & 0.34 & -0.25 \\
\hline Hansen test of over-id restrictions & 8.76 & 1.51 & 0.00 \\
\hline Prob $>$ Chi2 & 1 & 1 & 1 \\
\hline
\end{tabular}

${ }^{1}$ The dependant variable is NACAB/GDP. Estimation is by the GMM system estimator. Robust standard errors are in parentheses (*significant at 10\%;**significant at 5\%;***significant at $1 \%$ ). The Terms of Trade Index and Mean GDP per capita are measured in logs. 
Table 13: Aid Spending in Major Aid Receiving Countries ${ }^{1}$

NAGOB/GDP NAGOB/GDP NAGOB/GDP

Aid/GDP>0.02 Aid/GDP>0.05 Aid/GDP>0.1

\begin{tabular}{|c|c|c|c|}
\hline L. NAGOB/GDP & $\begin{array}{c}0.663 \\
(34.29)^{* * *}\end{array}$ & $\begin{array}{c}0.648 \\
(29.14)^{\star \star \star}\end{array}$ & $\begin{array}{c}0.630 \\
(31.78)^{\star * *}\end{array}$ \\
\hline Aid/GDP & $\begin{array}{l}-0.551 \\
(7.71)^{\star * *}\end{array}$ & $\begin{array}{l}-0.587 \\
(7.08)^{\star \star \star}\end{array}$ & $\begin{array}{l}-0.683 \\
(5.28)^{\star \star *}\end{array}$ \\
\hline Mean GDP per capita & $\begin{array}{l}-1.498 \\
(2.01)^{* *}\end{array}$ & $\begin{array}{l}-0.613 \\
(0.84)\end{array}$ & $\begin{array}{l}-0.753 \\
(1.32)\end{array}$ \\
\hline Index of Autocracy/Democracy & $\begin{array}{r}0.061 \\
(1.04)\end{array}$ & $\begin{array}{r}0.116 \\
(1.60)\end{array}$ & $\begin{array}{r}0.017 \\
(0.19)\end{array}$ \\
\hline Volatility of Aid & $\begin{array}{r}0.074 \\
(0.81)\end{array}$ & $\begin{array}{l}-0.066 \\
(0.68)\end{array}$ & $\begin{array}{l}-0.216 \\
(1.80)^{*}\end{array}$ \\
\hline Inflation & $\begin{array}{l}-0.458 \\
(1.26)\end{array}$ & $\begin{array}{l}-0.253 \\
(0.80)\end{array}$ & $\begin{array}{l}-1.348 \\
(2.03)^{* *}\end{array}$ \\
\hline Observations & 841 & 495 & 241 \\
\hline Number of Countries & 41 & 28 & 15 \\
\hline Arellano-Bond test for $\mathrm{AR}(1)$ & -3.24 & -2.61 & -1.95 \\
\hline Arellano-Bond test for $\operatorname{AR}(2)$ & -0.93 & -0.93 & -1.01 \\
\hline $\begin{array}{l}\text { Hansen test of over-id restrictions } \\
\text { Prob }>\text { Chi2 }\end{array}$ & $\begin{array}{c}14.11 \\
1\end{array}$ & $\begin{array}{l}2.42 \\
1\end{array}$ & $\begin{array}{l}0.00 \\
1\end{array}$ \\
\hline
\end{tabular}

${ }^{1}$ The dependant variable is NAGOB/GDP. Estimation is by the GMM system estimator. Robust standard errors are in parentheses (*significant at $10 \% ; * *$ significant at $5 \% ; * * *$ significant at $1 \%$ ). Mean GDP per capita and Inflation are measured in logs. 
Table 14: Reserve Accumulation Out of Aid - Major Aid Receiving Countries ${ }^{1}$

\begin{tabular}{|c|c|c|c|}
\hline & $\begin{array}{c}\Delta R / G D P \\
\text { Aid/GDP }>0.02\end{array}$ & $\begin{array}{c}\Delta R / G D P \\
\text { Aid/GDP }>0.05\end{array}$ & $\begin{array}{c}\Delta R / G D P \\
\text { Aid/GDP }>0.1\end{array}$ \\
\hline L. $\Delta R / G D P$ & $\begin{array}{c}0.058 \\
(0.77)\end{array}$ & $\begin{array}{c}0.059 \\
(0.71)\end{array}$ & $\begin{array}{l}-0.052 \\
(0.68)\end{array}$ \\
\hline Aid/GDP & $\begin{array}{c}0.050 \\
(1.36)\end{array}$ & $\begin{array}{c}0.059 \\
(1.51)\end{array}$ & $\begin{array}{c}0.055 \\
(1.12)\end{array}$ \\
\hline Terms of Trade Index & $\begin{array}{c}0.727 \\
(2.27)^{\star \star}\end{array}$ & $\begin{array}{c}0.726 \\
(2.42)^{\star \star}\end{array}$ & $\begin{array}{c}0.515 \\
(1.18)\end{array}$ \\
\hline Mean GDP per capita & $\begin{array}{c}0.581 \\
(1.67)^{*}\end{array}$ & $\begin{array}{c}0.471 \\
(1.91)^{*}\end{array}$ & $\begin{array}{c}0.275 \\
(2.10)^{\star \star}\end{array}$ \\
\hline Index of Autocracy/Democracy & $\begin{array}{c}0.015 \\
(0.53)\end{array}$ & $\begin{array}{c}0.035 \\
(1.20)\end{array}$ & $\begin{array}{r}0.040 \\
(1.36)\end{array}$ \\
\hline Volatility of aid & $\begin{array}{l}-0.020 \\
(0.35)\end{array}$ & $\begin{array}{l}-0.019 \\
(0.34)\end{array}$ & $\begin{array}{l}-0.015 \\
(0.48)\end{array}$ \\
\hline Observations & 1409 & 974 & 485 \\
\hline Number of Countries & 49 & 35 & 18 \\
\hline Arellano-Bond test for $\mathrm{AR}(1)$ & -3.34 & -3.04 & -3.09 \\
\hline Arellano-Bond test for AR(2) & 0.93 & 0.96 & -0.68 \\
\hline Hansen test of over-id restrictions & 11.17 & 7.24 & 0.00 \\
\hline Prob>Chi2 & 1 & 1 & 1 \\
\hline
\end{tabular}


Table 15: Impact of Aid on Investment-Major Aid Receiving Countries ${ }^{1}$

\begin{tabular}{|c|c|c|c|}
\hline & $\begin{array}{c}\text { I/GDP } \\
\text { Aid/GDP > } \\
0.02\end{array}$ & $\begin{array}{c}\text { I/GDP } \\
\text { Aid/GDP > } \\
0.05\end{array}$ & $\begin{array}{c}\text { I/GDP } \\
\text { Aid/GDP > } \\
0.1\end{array}$ \\
\hline L. I/GDP & $\begin{array}{c}0.443 \\
(0.115)^{\star * *}\end{array}$ & $\begin{array}{c}0.454 \\
(0.115)^{\star * *}\end{array}$ & $\begin{array}{c}0.417 \\
(0.112)^{\star * *}\end{array}$ \\
\hline Aid/GDP & $\begin{array}{c}0.144 \\
(0.032)^{\star * *}\end{array}$ & $\begin{array}{c}0.154 \\
(0.037)^{\star \star *}\end{array}$ & $\begin{array}{c}0.188 \\
(0.044)^{* * *}\end{array}$ \\
\hline Mean GDP per capita & $\begin{array}{c}0.392 \\
(0.408)\end{array}$ & $\begin{array}{c}0.481 \\
(0.453)\end{array}$ & $\begin{array}{c}0.162 \\
(0.559)\end{array}$ \\
\hline Terms of Trade Index & $\begin{array}{l}-1.742 \\
(0.801)^{\star *}\end{array}$ & $\begin{array}{l}-1.673 \\
(0.862)^{*}\end{array}$ & $\begin{array}{l}-0.585 \\
(1.743)\end{array}$ \\
\hline $\begin{array}{l}\text { Index of } \\
\text { Autocracy/Democracy }\end{array}$ & $\begin{array}{l}-0.001 \\
(0.050)\end{array}$ & $\begin{array}{l}-0.057 \\
(0.047)\end{array}$ & $\begin{array}{l}-0.044 \\
(0.058)\end{array}$ \\
\hline Volatility of Aid & $\begin{array}{l}0.229 \\
(0.094)^{\star *}\end{array}$ & $\begin{array}{c}.153 \\
(0.08)^{*}\end{array}$ & $\begin{array}{c}.246 \\
(0.13)^{\star}\end{array}$ \\
\hline Private I/GDP & $\begin{array}{c}0.578 \\
(0.092)^{\star * *}\end{array}$ & $\begin{array}{c}0.588 \\
(0.094)^{\star * *}\end{array}$ & $\begin{array}{c}0.675 \\
(0.066)^{\star * *}\end{array}$ \\
\hline Observations & 1227 & 823 & 389 \\
\hline Number of Countries & 49 & 35 & 18 \\
\hline Arellano-Bond test for $A R(1)$ & -3.27 & -2.80 & -2.43 \\
\hline Arellano-Bond test for $A R(2)$ & 0.92 & 0.86 & 1.16 \\
\hline $\begin{array}{l}\text { Hansen test of over-id } \\
\text { restrictions }\end{array}$ & 8.59 & 2.39 & 0.00 \\
\hline Prob $>$ Chi2 & 1 & 1 & 1 \\
\hline
\end{tabular}

${ }^{1}$ The dependant variable is Gross Fixed Capital Formation as a fraction of GDP, denoted I/GDP. Estimation is by the GMM system estimator. Robust standard errors are in parentheses (*significant at 10\%;**significant at $5 \% ; * *$ significant at 1\%). The Terms of Trade Index and Mean GDP per capita are measured in logs. 


\section{References}

Adam, Christopher S. and David L. Bevan, 2003, “Aid, Public Expenditure and Dutch Disease," Center for the Study of African Economies Working Paper, Working Paper No. 2003-02 (February).

Aiyar, Shekhar, Andrew Berg and Mumtaz Hussain, "The Macroeconomic Challenge of More Aid", Finance and Development, Volume 42, Number 3, September 2005.

Alesina, Alberto, and Beatrice Weder, 2002, "Do Corrupt Governments Receive Less Foreign Aid?", American Economic Review 92(4).

Bauer, Peter Tamas, 1971, "Foreign Aid: An Instrument for Progress?”, in P.T. Bauer and Barbara Ward, Two Views on Aid to Developing Countries (London: Institute of Economin Affairs)

Berg, Andrew, Shekhar Aiyar, Mumtaz Hussain, Shaun Roache, Tokhir Mirzoev, and Amber Mahone, 2007, "The Macroeconomics of Scaling-Up Aid: Lessons From Recent Experience", IMF Occasional Paper (forthcoming).

Bevan, David L., 2005, “An Analytic Overview of Aid Absorption: Recognizing and Avoiding Macroeconomic Hazards," paper presented at the Seminar on Foreign Aid and Macroeconomic Management, Maputo, March 14-15, 2005.

Bond, Stephen, 2002, "Dynamic Panel Data Models: A Guide to Micro Data Methods and Practice”, Portuguese Economic Journal, 1:141-162.

Boone, Peter, 1994, "The Impact of Aid on Savings and Growth", Centre for Economic Performance Working Paper No. 677, London School of Economics.

Boone, Peter, 1995, “Aid and Growth”, Mimeo, London School of Economics.

Boone, Peter, 1996, "Politics and the Effectiveness of Foreign Aid", European Economic Review, 40(2).

Bosworth, Barry, and Susan Collins, 1999, "Capital Flows to Developing Economies: Implications for Savings and Investment", Brookings Papers on Economin Activity: Brookings Institution.

Burnside, Craig and David Dollar, "Aid, Policies and Growth", American Economic Review, Vol 90 (4), September 2000. 
Clemens, Michael, Steven Radelet, and Rikhil Bhavnani, 2004, "Counting Chickens When they Hatch: The Short-Term Effect of Aid on Growth," Working Paper 4,(Washington: Center for Global Development).

Collier, Paul, and David Dollar, 2002, “Aid Allocation and Poverty Reduction”, European Economic Review, vol. 46(8).

Dalgaard, Carl-Johan, Henrik Hansen and Finn Tarp, 2004, "On the Empirics of Foreign Aid and Growth”, Economic Journal, vol. 114(496).

Easterly, William, Ross Levin, and David Roodman, 2003, "New Data, New Doubts: A Comment on Burnside's and Dollar's 'Aid, Policies and Growth'," National Bureau of Economic Research Working Paper Series, No. 9846 (July), pp.1-18.

Eble, Alex, 2006, "New Data, Old Doubts—Reexamination of Aid, Investment and Consumption", Unpublished manuscript.

Foster, Mick, and Tony Killick, 2006, "What Would Doubling of Aid do for Macroeconomic Management in Africa?," ODI Working Paper 264 (Overseas Development Institute, April).

Gupta, Sanjeev, Robert Powell, and Yongzheng Yang, 2006, Macroeconomic Challenges of Scaling Up Aid to Africa: A Checklist for Practitioners (Washington: International Monetary Fund).

Hansen, Henrik, and Finn Tarp, "Aid and Growth Regressions", Journal of Development Economics, 64.

Independent Evaluation Office (IEO), International Monetary Fund, “An Evaluation of the IMF and Aid to Sub-Saharan Africa" (Washington, March 2007).

International Monetary Fund, 2005, “The Macroeconomics of Managing Aid Inflows: Experiences of Low-Income Countries and Policy Implications" (Washington, August 8). Available via the Internet: http://www.imf.org/external/np/pp/eng/2005/080805a.htm

Isard, Peter, Leslie Lipschitz, Alexandros Mormouras and Boriana Yontcheva (eds), 2006, The Macroeconomic Management of Foreign Aid: Opportunities and Pitfalls (Washington: International Monetary Fund).

Judson, Ruth, and Ann Owen, 1999, "Estimating Dynamic Panel Data Models: A Guide for Macroeconomists", Economics Letters, 65: 9-15. 
Peiris, Jay and Magnus Saxegaard, "Monetary Policy Rules in Sub-Saharan Africa", IMF Working Paper (forthcoming).

Rajan, R, and A. Subramanian, 2005, “Aid and Growth: What Does the Cross-Country Evidence Really Show?” IMF Working Paper, 05/127 (June), (Washington: International Monetary Fund).

Roodman, David, 2004, “The Anarchy of Numbers: Aid, Development and Cross-Country Empirics" (Washington: Center for Global Development)

Svensson, Jacob, 2003, "Why Conditional Aid Doesn't Work and What Can Be Done About It", Journal of Development Economics, 70(2). 
Appendix I: Sample Countries

\begin{tabular}{|c|c|c|c|}
\hline Country & Region & Kenya & AFR \\
\hline Albania & $\mathrm{OC}$ & Lebanon & $\mathrm{OC}$ \\
\hline Algeria & AFR & Lesotho & AFR \\
\hline Armenia & $\mathrm{OC}$ & Madagascar & AFR \\
\hline Bangladesh & $\mathrm{OC}$ & Malawi & AFR \\
\hline Belize & LAC & Malaysia & $\mathrm{OC}$ \\
\hline Benin & AFR & Maldives & $\mathrm{OC}$ \\
\hline Bhutan & $\mathrm{OC}$ & Mali & AFR \\
\hline Bolivia & LAC & Mauritania & AFR \\
\hline Botswana & AFR & Mauritius & AFR \\
\hline Brazil & LAC & Mexico & LAC \\
\hline Burkina Faso & AFR & Morocco & AFR \\
\hline Burundi & AFR & Mozambique & AFR \\
\hline Cameroon & AFR & Nepal & $\mathrm{OC}$ \\
\hline Cape Verde & AFR & Niger & AFR \\
\hline Central African Rep. & AFR & Nigeria & AFR \\
\hline Chad & AFR & Pakistan & $\mathrm{OC}$ \\
\hline Chile & LAC & Panama & LAC \\
\hline China,P.R.: Mainland & $\mathrm{OC}$ & Papua New Guinea & $\mathrm{OC}$ \\
\hline Colombia & LAC & Paraguay & LAC \\
\hline Comoros & AFR & Philippines & $\mathrm{OC}$ \\
\hline Congo, Republic of & AFR & Romania & $\mathrm{OC}$ \\
\hline Costa Rica & LAC & Rwanda & AFR \\
\hline Côte d'Ivoire & AFR & Senegal & AFR \\
\hline Djibouti & AFR & Seychelles & AFR \\
\hline Dominica & $\mathrm{OC}$ & Sierra Leone & AFR \\
\hline Dominican Republic & LAC & South Africa & AFR \\
\hline Ecuador & LAC & Sri Lanka & $\mathrm{OC}$ \\
\hline Egypt & $\mathrm{OC}$ & St. Lucia & $\mathrm{OC}$ \\
\hline El Salvador & LAC & St. Vincent \& Grens. & $\mathrm{OC}$ \\
\hline Equatorial Guinea & AFR & Sudan & AFR \\
\hline Ethiopia & AFR & Swaziland & AFR \\
\hline Fiji & $\mathrm{OC}$ & Syrian Arab Republic & $\mathrm{OC}$ \\
\hline Gabon & AFR & São Tomé \& Príncipe & AFR \\
\hline Gambia, The & AFR & Tanzania & AFR \\
\hline Ghana & AFR & Thailand & $\mathrm{OC}$ \\
\hline Grenada & $\mathrm{OC}$ & Togo & AFR \\
\hline Guatemala & LAC & Tonga & $\mathrm{OC}$ \\
\hline Guinea & AFR & Trinidad and Tobago & LAC \\
\hline Guinea-Bissau & AFR & Tunisia & AFR \\
\hline Guyana & $\mathrm{OC}$ & Turkey & $\mathrm{OC}$ \\
\hline Haiti & LAC & Uganda & AFR \\
\hline Honduras & LAC & Uruguay & LAC \\
\hline Hungary & $\mathrm{OC}$ & Venezuela, Rep. Bol. & LAC \\
\hline India & $\mathrm{OC}$ & Vietnam & $\mathrm{OC}$ \\
\hline Indonesia & $\mathrm{OC}$ & Zambia & AFR \\
\hline Iran, I.R. of & $\mathrm{OC}$ & Zimbabwe & AFR \\
\hline Jamaica & LAC & & \\
\hline Country & Region & & \\
\hline Jordan & $\mathrm{OC}$ & & \\
\hline
\end{tabular}

